\title{
The Constitutional Role OF THE COURTS UNDER THE NZ BILL OF RIGHTS: THREE NARRATIVES FROM ATTORNEY-GENERAL V TAYLOR
}

\section{Claudia Geiringer*}

\begin{abstract}
In Attorney-General v Taylor, New Zealand's Court of Appeal upheld the High Court's recognition, and exercise, of an implied jurisdiction to make (non-binding) declarations of legislative inconsistency with the New Zealand Bill of Rights Act 1990 (the NZ Bill of Rights). Recognition of this novel jurisdiction says something important about the evolution of judicial-legislative relations under the NZ Bill of Rights. The question is: what exactly? This article suggests that a close analysis of the Court of Appeal's decision in Taylor in fact discloses three interwoven narratives that speak to the constitutional role of the courts in enforcing the NZ Bill of Rights: the NZ Bill of Rights as "legal benchmark"; the NZ Bill of Rights as "facilitator of inter-branch dialogue"; and the "common lawfuelled bill of rights". The article unpicks these narratives, explores the relationship between them and discusses the extent to which they succeed in accommodating or justifying the new declaratory remedy.
\end{abstract}

\section{INTRODUCTION}

How might we characterise the constitutional role of the courts under the New Zealand Bill of Rights Act 1990 (the NZ Bill of Rights)? Was the enactment of that instrument a moment of departure heralding a significant new role for the courts, in particular, in developing their relationship with the political branches? Or was it a business-as-usual restatement of existing constitutional principle - one that gently reshaped, but did not fundamentally reconfigure, existing roles? If the NZ Bill of Rights

Professor and Chair in Public Law, Faculty of Law, Victoria University of Wellington; Co-Director, New Zealand Centre for Public Law. This article is based on a paper presented at the Institute of Judicial Studies symposium "Challenge and Change" (Wellington, 2017). Thanks for their comments to my co-presenter at the relevant session, John Burrows QC, to my colleagues Graeme Austin, Dean Knight and Geoff McLay, and to the anonymous reviewer. Thanks also to three research assistants for help with different aspects of the project: Carlos Smith Díaz, Ruby King and Etienne Wain. 
heralded a constitutional change or departure, what was the nature of that change? And if it heralded constitutional continuity, what exactly was being continued?

As has been suggested elsewhere, the answer to these, and other, questions about the constitutional significance of the NZ Bill of Rights is contested and uncertain. ${ }^{1}$ Writing in 1996, for example, Anna Adams identified three competing discourses about the constitutional significance of the NZ Bill of Rights emerging from the Cooke era jurisprudence alone. ${ }^{2}$ More recently, Paul Rishworth has suggested that, as compared with its international comparators, the NZ Bill of Rights is "uniquely hobbled by uncertainty over its purpose". ${ }^{3}$ Rishworth identifies two competing narratives about the constitutional significance of the NZ Bill of Rights - one that sees the NZ Bill of Rights as "ordinary" or "parliamentary" and the other that sees it as "constitutional". ${ }^{4}$ In the comparative literature, competing theories about the constitutional significance of the NZ Bill of Rights also abound. ${ }^{5}$

As is well known, the seeds of this ambivalence about the constitutional significance of the NZ Bill of Rights were sown at the very moment of its enactment - both in the absence of a strong founding narrative, and in aspects of equivocation or contradiction in the text itself. ${ }^{6}$ As to the former, the authors of the 1985 White Paper (from which the NZ Bill of Rights ultimately emerged) had a

1 For example Andrew Geddis and MB Rodriguez Ferrere "Judicial Innovation under the New Zealand Bill of Rights Act - Lessons for Queensland" (2016) 35 UQLJ 251 at 259; and Claudia Geiringer "What's the story? The instability of the Australasian bills of rights" (2016) 14 ICON 156.

2 Anna Adams "Competing Conceptions of the Constitution: The New Zealand Bill of Rights Act 1990 and the Cooke Court of Appeal" [1996] NZ Law Review 368. They were: the NZ Bill of Rights as a new moral charter; the NZ Bill of Rights as a stimulus of methodological change; and the NZ Bill of Rights as an affirmation of existing rights.

3 Paul Rishworth "The Supreme Court and the Bill of Rights" in Andrew Stockley and Michael Littlewood (eds) The New Zealand Supreme Court: The First Ten Years (LexisNexis, Wellington, 2015) 169 at 171.

4 Paul Rishworth "The Bill of Rights and 'Rights Dialogue' in New Zealand: After 20 Years, What Counts as Success?" (paper presented at the University of Sydney Workshop on Judicial Supremacy or InterInstitutional Dialogue: Political Responses to Judicial Review, Sydney, May 2010); and Rishworth, above n 3 (but suggesting, at 191, that the first decade of jurisprudence of the emergent Supreme Court of New Zealand contains the seeds of a resolution of this conundrum in favour of the constitutional narrative). The implications of this contrast between an ordinary and a constitutional narrative are explored further in Geiringer, above $n$ 1.

5 See for example Stephen Gardbaum The New Commonwealth Model of Constitutionalism: Theory and Practice (Cambridge University Press, Cambridge, 2013); Ran Hirschl Towards Juristocracy: The Origins and Consequences of the New Constitutionalism (Harvard University Press, Cambridge (Mass), 2004); and Scott Stephenson From Dialogue to Disagreement in Comparative Rights Constitutionalism (Federation Press, Sydney, 2016).

6 See Rishworth, above n 3, at 171-176; Rishworth, above n 4, at 4-8; Geddis and Rodriguez Ferrere, above $n$ 1, at 256-258; and Geiringer, above n 1, at 169-170. 
clear and articulated vision of the constitutional significance of their draft supreme law instrument. ${ }^{7}$ But no similar process of constitutional theorisation accompanied the Act's transformation into "ordinary law". New Zealand's statutory bill of rights was imagined into being, not so much as a constitutional innovation, but as a battered memento, salvaged from the ruins of its framers' shattered dreams. To this day, its political sponsor Sir Geoffrey Palmer considers it a pale, insipid kind of a thing, ${ }^{8}$ and remains unmoved by the growing body of international scholarship that seeks to rehabilitate the statutory bill of rights model as a constitutional triumph of the middle ground. ${ }^{9}$

At its moment of founding, then, the NZ Bill of Rights was defined (at least in constitutional terms) less by what it was, than by what it was not. ${ }^{10}$ It was not a supreme law instrument, and did not empower the courts to disapply legislation. That much was clear. But once that high ground was cleared away, what was to be viewed underneath remained somewhat out of focus.

That blurriness is underpinned by elements of equivocation in the enacted text. The fact is that, even following the removal of supremacy, entrenchment and remedies clauses (and the last-minute addition of the insistently worded s 4), ${ }^{11}$ much of the architecture of a constitutional instrument still remains. ${ }^{12}$ First, there is the intrinsic importance (and arguably, constitutional character) of the normative commitments that the NZ Bill of Rights entails. ${ }^{13}$ Secondly, there is the specification in s 3 that the Act "applies" to acts done by the legislative (as well as judicial and executive) branches. And then thirdly, and perhaps most importantly, there is s 5, asserting the illegitimacy of unreasonable

7 Department of Justice A Bill of Rights for New Zealand: A White Paper (1985) [White Paper]. See also KJ Keith "A Bill of Rights for New Zealand? Judicial Review versus Democracy" (1985) 11 NZULR 307; and DAR Williams "Some Operational Aspects of the Bill of Rights" in Legal Research Foundation (ed) A Bill of Rights for New Zealand (Legal Research Foundation, Auckland, 1985) 75.

8 My words, not his. But see for example Geoffrey Palmer "What the New Zealand Bill of Rights Aimed to Do, Why it did not Succeed and How it can be Repaired" (2016) 14 NZJPIL 169.

9 For example Gardbaum, above $\mathrm{n} 5$.

10 Rishworth, above n 3, at 172; and Paul Rishworth "The Birth and Rebirth of the Bill of Rights" in Grant Huscroft and Paul Rishworth (eds) The New Zealand Bill of Rights Act 1990 and the Human Rights Act 1993 (Brookers, Wellington, 1995) 1 at 25.

11 "No court shall, in relation to any enactment (whether passed or made before or after the commencement of this Bill of Rights), -

(a) hold any provision of the enactment to be impliedly repealed or revoked, or to be in any way invalid or ineffective; or

(b) decline to apply any provision of the enactment-

by reason only that the provision is inconsistent with any provision of this Bill of Rights."

12 See Rishworth, above $\mathrm{n} 4$, at 8.

13 Rishworth, above n 10, at 28. 
limits on rights. ${ }^{14}$ In the event of conflict between ss 4 and 5, it is s 4 that prevails. But this does not negate the fact that these two operative clauses pull in distinctly different directions. Further, s 4 , though emphatic, is drafted in economical language; it rules out certain specified judicial remedies for legislative non-compliance but does not proclaim, in more capacious terms, the constitutional legitimacy of non-compliant legislation. ${ }^{15}$

The text of the NZ Bill of Rights thus embodies at its heart a fundamental ambivalence as to its constitutional status and effect. We should not be surprised that (as Rishworth points out) a consistent and shared narrative about what "it mean[s] to have a Bill of Rights in New Zealand" has been slow to emerge. ${ }^{16}$

Enter Attorney-General v Taylor, in which a unanimous Bench of five members of the Court of Appeal upheld the High Court's first exercise of an implied jurisdiction to make (non-binding) declarations of legislative inconsistency with the NZ Bill of Rights. ${ }^{17}$ Although a further appeal is pending, ${ }^{18}$ the result in the Court of Appeal decision hardly took the punters by surprise. The New Zealand courts have, after all, been circling around the idea of such a remedial jurisdiction almost since the NZ Bill of Rights was first enacted. ${ }^{19}$ And with the way paved by High Court Justices Brown (recognising the jurisdiction) ${ }^{20}$ and Heath (exercising it), ${ }^{21}$ excuses for the Court of Appeal to (yet again) duck for cover on the issue seemed thin on the ground. If not in this case, then when ${ }^{22}$

Nevertheless, by any measure, the emphatic confirmation of (and exercise of) an implied jurisdiction to make declarations of legislative inconsistency is an important moment in the evolution

14 "Subject to section 4, the rights and freedoms contained in this Bill of Rights may be subject only to such reasonable limits prescribed by law as can be demonstrably justified in a free and democratic society."

15 See Andrew S Butler "Judicial Indications of Inconsistency - A New Weapon in the Bill of Rights Armoury?" [2000] NZ L Rev 43 at 51.

16 Rishworth, above $\mathrm{n} 4$, at 1 .

17 Attorney-General v Taylor [2017] NZCA 215, [2017] 3 NZLR 24 [Taylor (CA)].

18 Attorney-General v Taylor [2017] NZSC 131 (granting leave to appeal). Following the change of government in October 2017, the date for the hearing of the appeal was deferred. But, at least at the time this article went to press, the appeal was still on foot.

19 See Temese v Police (1992) 9 CRNZ 425 (CA) at 427 per Cooke P citing FM Brookfield "Constitutional Law" [1992] NZ Recent Law Review 231 at 239. The intervening case law is discussed in Claudia Geiringer "On a Road to Nowhere: Implied Declarations of Inconsistency and the New Zealand Bill of Rights Act" (2009) 40 VUWLR 613. Although I documented in that article judicial resistance to recognition of the jurisdiction, I also predicted at 637 that the courts would eventually take the plunge.

20 Taylor v Attorney-General [2014] NZHC 1630 [Taylor (strike out)].

21 Taylor v Attorney-General [2015] NZHC 1706, [2015] 3 NZLR 791 [Taylor (HC)].

22 See Andrew Geddis "New Zealand: prisoner voting and consistency with the New Zealand Bill of Rights Act 1990" [2016] PL 352 at 352, describing Taylor (HC), above n 21, as a "compelling case for such relief". 
of judicial-legislative relations under the NZ Bill of Rights. When all is said and done, the new remedial jurisdiction comprises a judicial power to make non-binding declarations of legal nonright. ${ }^{23}$ Surely we can all agree that this is not quite business as usual when it comes to traditional understandings of the judicial function. ${ }^{24}$ Recognition of such a jurisdiction, therefore, seems to say something important about that function, and about the constitutional role of the courts under the NZ Bill of Rights. The question is: what, exactly?

As it happens, the Court of Appeal's painstaking attempt in Taylor to grapple with the nature of New Zealand's constitutional arrangements, and with the place of the NZ Bill of Rights within them, provides ample stimulus for reflection on that question. When we subject the decision to close analysis, however, we discover that not all of what it has to say about the constitutional basis for its decision pulls in quite the same direction. Indeed, I suggest in this article that Taylor discloses three closely interwoven narratives that speak to the constitutional role of the courts in enforcing the NZ Bill of Rights. I call these "the NZ Bill of Rights as legal benchmark"; "the NZ Bill of Rights as facilitator of inter-branch dialogue"; and "the common law-fuelled bill of rights".

In this article, I unpick these three narratives, explore the relationship between them, and discuss the extent to which they succeed in accommodating or justifying the new declaratory remedy. I suggest that the first narrative, explored in Part III, is grounded in an orthodox Diceyan conception of the role of judges in finding, declaring and enforcing "law". For that reason, it fails on its own terms to justify the novelty of the new declaratory remedy (and specifically the new role of the courts in declaring a non-binding form of law).

The second narrative, explored in Part IV, is hampered by ambiguity about what we mean when we talk of constitutional "dialogue". A radical vision of what such dialogue entails might, indeed, succeed in explaining or justifying the new jurisdiction. But such a vision is in tension with the first narrative, constitutes a dramatic departure from New Zealand's constitutional traditions, and is not, on a close reading, what the Court of Appeal appears to envisage. On the other hand, the more constitutionally orthodox account of dialogue that the Taylor Court, in fact, seems to have in mind has the disadvantage that it has less explanatory power. It is not immediately clear (at least without further exploration) what it adds to the idea inherent in the first narrative that the courts' role in our constitution is to find and declare "law".

23 See Taylor (CA), above n 17, at [66]: "We accept that a [declaration of inconsistency] is not a declaration of right. It determines no legal rights and conveys no legal consequences as between the parties".

24 For a traditional explication of that function in the New Zealand context, see for example KJ Scott The New Zealand Constitution (Clarendon Press, Oxford, 1962) at 157-160. See further Butler, above n 15, at 55 and 58 describing the remedy as a "practical recalibration of the separation of powers" and "a profound paradigm shift in New Zealand public law discourse"; Tom Hickman "Bill of Rights Reform and the Case for Going Beyond the Declaration of Incompatibility Model" [2015] NZ L Rev 35 at 48-49; and Stephenson, above n 5 , at $129-130$ 
That further exploration is, however, arguably supplied by the third narrative, which looks primarily to the authority of the common law to justify the new remedy. In Part V, I suggest that this third narrative underlies the other two, and knits together the Court's vision of the significance of the NZ Bill of Rights within New Zealand's constitutional arrangements. I also suggest that this narrative is the most interesting and revealing. It reminds us that the NZ Bill of Rights must somehow be explained within our existing constitutional paradigm. But it also reminds us that this paradigm is, itself, sufficiently flexible to accommodate renewal. The wisdom of the Court of Appeal's decision lies, in particular, in its recognition that the undoubted novelty of the new declaratory remedy can be accommodated (all other factors being equal) within an evolving, but enduring, common law tradition.

But if the common law can provide a basis for renewal and transformation, it does not have to. Resort to the authority of the common law cannot provide the answer to the ultimate question whether the new jurisdiction should be recognised. But, as I suggest in Part VI, it does have something interesting to say about the framework within which that question needs be addressed.

\section{DECLARATIONS OF INCONSISTENCY - SOME BRIEF BACKGROUND}

In brief, in the New Zealand context, a declaration of inconsistency amounts to a formal but nonbinding declaration that an Act of the New Zealand Parliament is incompatible with the NZ Bill of Rights. The power to make non-binding declarations of this kind is an express feature of statutory human rights regimes in a number of other jurisdictions (where they are variously known as declarations of incompatibility, or of inconsistent interpretation). ${ }^{25}$ Since 2001, such a jurisdiction has also been an express legislative feature of the New Zealand landscape, when it was conferred on the Human Rights Review Tribunal but only in relation to unjustified breaches of the right in s 19 of the NZ Bill of Rights to freedom from discrimination. ${ }^{26}$

The NZ Bill of Rights, on the other hand, does not specify the existence of any such relief. That has not stopped some commentators and, indeed, some judges from speculating as to whether such a power can be read into the NZ Bill of Rights by implication. ${ }^{27}$ But prior to Taylor, the jurisdiction had never been conclusively recognised, let alone exercised.

25 See Human Rights Act 1998 (UK), s 4; European Convention on Human Rights Act 2003 (Ireland), s 5; Human Rights Act 2004 (ACT), s 32; and Charter of Human Rights and Responsibilities Act 2006 (Vic), s 36. But see below $n 53$, discussing the fact that no such declaration has been made (or at least has survived appeal) in either of the Australian sub-national jurisdictions.

26 See Human Rights Act 1993, s 92J, introduced by the Human Rights Amendment Act 2001.

27 For early commentary on the possibility of such a jurisdiction, see Brookfield, above n 19, at 239; Philip A Joseph "The New Zealand Bill of Rights" (1996) 7 PLR 162 at 167; and Paul Rishworth "Reflections on the Bill of Rights after Quilter v Attorney-General" [1998] NZ Law Review 683 at 689-695. For a survey of the pre-Taylor case law, see Geiringer, above n 19. 
In Taylor, however, the High Court finally took the bit between its teeth. Taylor concerned a blanket legislative ban on prisoner voting - a ban that even the Attorney-General (in his report to Parliament under s 7 of the NZ Bill of Rights) thought constituted an unjustified limit on the right to vote in s 12(a) of the NZ Bill of Rights. ${ }^{28}$ Five prisoners challenged the legislation seeking, amongst other things, a formal declaration that the legislation was inconsistent with s 12 (a). ${ }^{29}$ In a strike out decision, Brown $\mathrm{J}$ held that the High Court did have such a jurisdiction (but expressed considerable caution as to the circumstances in which it might be exercised). ${ }^{30}$ When the case came back to the High Court for the substance of the application to be determined, Heath J not only agreed with Brown $\mathbf{J}$ as to the existence of such a jurisdiction, but was prepared to exercise it on the facts of the case. ${ }^{31}$

It is the Attorney-General's appeal from that decision with which we are concerned. ${ }^{32}$ On appeal, the Court agreed both that the High Court has such a jurisdiction and that it was appropriate for Heath $\mathrm{J}$ to have exercised it in the circumstances. As noted above, however, this article focuses not so much on the destination as on the journey. The article suggests that the Court of Appeal's decision discloses three distinct, if interwoven, narratives about the constitutional role of the courts under the NZ Bill of Rights. It is to these three narratives that we now turn.

\section{NARRATIVE ONE: THE NZ BILL OF RIGHTS AS LEGAL BENCHMARK}

The first narrative thread found in the Taylor decision emphasises the role of the NZ Bill of Rights as a "legal benchmark", enforced or declared by judges. In exploring this narrative, we might helpfully break it down into two reinforcing ideas. The first is that the NZ Bill of Rights functions as a sort of normative baseline by which the legitimacy of state action - including legislative action - is to be assessed. The second is that this normative baseline constitutes "law" which, in accordance with orthodox constitutional principle, is to be enforced or declared by judges.

Let us take, first, the idea of the NZ Bill of Rights as a benchmark, or yardstick, against which to measure the legitimacy of state action. This is, of course, how supreme law bills of rights operate: by binding all organs of the state, including the legislature, to a set of minimum standards against which

28 Christopher Finlayson Report of the Attorney-General under the New Zealand Bill of Rights Act 1990 on the Electoral (Disqualification of Convicted Prisoners) Amendment Bill (2010). For a fuller discussion, see Geddis, above $\mathrm{n} 22$ (commenting on the High Court decision).

29 See also Taylor v Attorney-General [2016] NZHC 355, [2016] 3 NZLR 111 [Taylor (entrenchment decision)]; and Ngaronoa v Attorney-General [2017] NZCA 351, [2017] 3 NZLR 643 (determining separately other aspects of the prisoners' claim).

30 Taylor (strike out), above n 20.

31 Taylor (HC), above n 21.

32 Taylor (CA), above n 17. 
their actions can be assessed. ${ }^{33}$ And according to one, increasingly dominant, reading of its operative provisions, the NZ Bill of Rights is - at least in this respect - no different. ${ }^{34}$ The combined effect of ss 3, 5 and 6 (together with the normative force of the protected rights) is that the NZ Bill of Rights, too, functions as a minimum standard governing all state action - albeit one that is subject to the very specific statutory subtractions found in $\mathrm{s} 4$.

This idea of the NZ Bill of Rights as normative baseline places s 5, and its standard of demonstrable justification, at the centre of the scheme of protection. It is $\mathrm{s} 5$ that sets the minimum standard; that dictates which state interventions are legitimate, and which are not. And this threshold for legitimate action then feeds into government decision-making through the mechanisms of s 3 (applying the NZ Bill of Rights to state actors, including the legislature), s 6 (preferring rightsconsistent interpretations of enactments) and s 7 (requiring Attorney-General reports on rightsinconsistent legislation).

Rishworth argues that this idea of the NZ Bill of Rights as "a standard for all law" is now in jurisprudential ascendency - at least if the first decade of case law from the Supreme Court is anything to go by. ${ }^{35}$ Whether or not that is so, ${ }^{36}$ this idea of the NZ Bill of Rights as normative baseline certainly helps us to make sense of the Supreme Court's approach to the role of the NZ Bill of Rights in statutory interpretation - that the courts should interpolate s 5 into the s 6 interpretive direction. ${ }^{37}$ According to the Judges that formed the majority on this point in the leading decision of $R v$ Hansen, 5 of the NZ Bill of Rights contains a standard against which both the courts and, indeed, Parliament itself are to measure the "legitimacy" of incursions on protected rights. On the other hand, s 5 also "legitimises" limits on rights that can be demonstrably justified. For that reason, the s 6 interpretive direction does not come into play until s 5 is first engaged. ${ }^{38}$

33 See for example White Paper, above n 7, at [1].

34 This idea of the NZ Bill of Rights as a normative baseline is identified particularly strongly with the scholarship of Paul Rishworth: for example Paul Rishworth and others (eds) The New Zealand Bill of Rights (Oxford University Press, Melbourne, 2003) at 3-5, 26-31, 72 and 118-119; and Rishworth, above n 3, at 176. See also Andrew Butler and Petra Butler The New Zealand Bill of Rights Act: A Commentary (2nd ed, LexisNexis, Wellington, 2015) at [28.5.6]-[28.5.7]; Claudia Geiringer "Sources of Resistance to Proportionality Review under the New Zealand Bill of Rights Act" (2013) 11 NZJPIL 123 at 139-141; and Constitutional Advisory Panel New Zealand's Constitution: A Report on a Conversation (2013) at 49.

35 Rishworth, above $\mathrm{n} 3$.

36 See Geiringer, above $\mathrm{n}$ 1, at 160, suggesting that the appearance of resolution may be somewhat illusory. See also David AC Bullock "The Wane of s 5 of the New Zealand Bill of Rights Act 1990" [2017] NZLJ 164

$37 \quad R v$ Hansen [2007] NZSC 7, [2007] 3 NZLR 1.

38 At [82] per Blanchard J, at [90]-[91] and [106] per Tipping J, and at [186], [207] and [259] per McGrath J. Contrast at [19] per Elias CJ. 
In Taylor, we see the Court of Appeal drawing on the majority judgments in Hansen to support a similar line of reasoning. ${ }^{39}$ The Court reminds us that s 3 of the NZ Bill of Rights "expressly applies" the Act to each of the three branches of Government. ${ }^{40}$ As long as it remains on the statute book, the Act (and s 5 in particular) "applies to Parliament itself, just as it does to the other branches". ${ }^{41}$

So, then, the NZ Bill of Rights functions (according to the Taylor Court) as a normative benchmark, which applies to Parliament through the mechanisms of ss 3 and 5. But that does not, in itself, explain or justify the role of the courts in upholding this standard of constitutional legitimacy, as against Parliament, through the mechanism of a non-binding declaration. For that, we must turn to the second strand in the legal benchmark narrative. It lies in the Taylor Court's assertion that the question whether legislation is (in)compatible with the NZ Bill of Rights is a question of "law", and therefore within the province of the courts. ${ }^{42}$ Even Parliament, so the Court opines, is subject to constraints - some of which are "legal in nature" ${ }^{43}$ These include the rule that Parliament cannot bind its successors, and the rule that for a Bill to become law, it must be passed by the House of Representatives and given royal assent. ${ }^{44}$ When Parliament's legal authority is called into question "recourse must be had to the courts, both for an authoritative answer and as a practical necessity". ${ }^{45}$ The question of inconsistency between two statutes is such a question of law, and is therefore within the province of the courts.

This is an intriguing move - echoing, as it does, the celebrated play made by Marshall CJ, in Marbury $v$ Madison, in establishing the American institution of judicial review of legislation: ${ }^{46}$

39 At [79]-[83].

40 At [79].

41 At [79].

42 At [53]-[62] and [77].

43 At [53].

44 At [53] and [55]. The Court also referred at [54] to the historical position in New Zealand, when the courts had authority to pronounce unlawful "colonial legislation found to be inconsistent with authority derived from Westminster", and to the possibility reflected in $R$ (Jackson) v Attorney General [2005] UKHL 56, [2006] 1 AC 262 and in British case law associated with the enforceability of the European Communities Act 1972 (UK) that the courts might enforce constraints placed on Parliament by statute. The omission of any reference here to the enforceability of the entrenchment formula found in s 268 of the Electoral Act 1993 is striking, but might be due to the fact that this provision was squarely before the Court in a related appeal from which decision was then reserved: see Taylor (entrenchment decision), above n 29; and Ngaronoa v AttorneyGeneral, above n 29.

45 At [56].

46 Marbury v Madison 5 US 137 (1803) at 177. See Rishworth, above n 3, at 175, suggesting that Moonen v Film and Literature Board of Review [2000] 2 NZLR 9 (CA) - a case that he regards as an early forerunner 
It is emphatically the province and duty of the judicial department to say what the law is. Those who apply the rule to particular cases, must of necessity expound and interpret that rule. If two laws conflict with each other, the courts must decide on the operation of each.

There is irony here if we wish to look for it. The veracity of Marshall CJ's claim may seem obvious to us now, but it was hardly so for the founding generation in the United States. For them, it was by no means self-evident that a question of constitutional compatibility was a question of law - at least not in the sense of a body of rules interpreted and enforced by judges. Rather, as Larry Kramer explains, a constitution was seen at that time as a special and distinct form of popular law, enforced not by courts but by the people. ${ }^{47}$ The genius of Marshall CJ's play was in locating the United States Constitution as a subset of ordinary (in the sense of court-enforced) law and, in doing so, legitimising an expansion in the reach of judicial power.

If Marshall CJ was innovating as much as he was declaring, might not the same also be said of the Taylor Court's claim that the question of legislative (in)compatibility with the NZ Bill of Rights is a question of law-expounded-by-judges? After all, as we have seen, the Taylor Court accepts that the resolution of "incompatibility proceedings" does not determine any legal rights or convey legal consequences to the parties. ${ }^{48}$ For sure, it is part of the traditional judicial role to resolve questions of inconsistency between two statutes. But, having applied all relevant rules of interpretation or priority, a court would ordinarily settle on one version of the "law" - that which binds the parties. The implication of the Taylor decision is that the relevant "law" is, simultaneously, that which binds the parties (in this case, s 80 of the Electoral Act 1993) and that which is found in the NZ Bill of Rights but does not, in the particular circumstances, bind the parties. Surely there is some constitutional novelty here.

In any event, the Taylor Court's characterisation of the question of legislative (in)compatibility as one of law-expounded-by-judges helpfully illuminates the logic underlying the legal benchmark narrative. We see the way it draws on, and extends, Diceyan notions of the supremacy and objectivity of law, of the subjection of officials to rule by and under it, and of the independent role of judges in finding, declaring and enforcing it. ${ }^{49}$ The logic of the legal benchmark narrative is that all this applies to the NZ Bill of Rights in its relationship with Parliament subject to one (significant but circumscribed) statutory subtraction: that the courts cannot deliver those remedies specifically

of what I describe here as the legal benchmark narrative (and what he describes as the constitutional narrative) - was "New Zealand's Marbury v Madison".

47 See Larry D Kramer "The Supreme Court 2000 Term. Foreword: We the Court" (2001) 115 Harv L Rev 4 at 8-12 and Part II.

48 At [66] and [149].

49 See AV Dicey Introduction to the Study of the Law of the Constitution (10th ed, Macmillan, London, 1959) at ch 4 especially. 
precluded by s 4 . Despite this legislated exception, the courts are still under a duty to "vindicate" the legal rights at stake and to provide, as far as possible, "effective remedies" - functions that may, in appropriate cases, be advanced by a formal declaration..$^{50}$

The weak spot in this narrative (at least for an attempt to justify the new remedial jurisdiction) is that it struggles to account for the circumscribed role of the courts under the NZ Bill of Rights. If the question of legislative compatibility is one of law to which Parliament is subject, and if it is the role of the courts to find and declare that law, then how do we explain, in constitutional terms, the fact that the pronouncements of the judiciary to this effect are not binding and enforceable? The idea that the courts might declare a form of non-binding law (one that, indeed, must give way to other law that does bind the parties) does not sit easily with a legalist account of this kind. Dicey himself would certainly have regarded this as a departure from the judicial function. ${ }^{51}$

The considerable disquiet expressed by the High Court of Australia in Momcilovic v The Queen about the power to make such declarations is best understood in this light. ${ }^{52}$ In the High Court's view, the power conferred on the Victorian Supreme Court under s 36 of Victoria's Charter of Human Rights and Responsibilities Act 2006 to make non-binding declarations of "inconsistent interpretation" is not a judicial power properly so-called, and is therefore inconsistent with the formalist separation of federal judicial power found in Chapter III of the Australian federal Constitution. This means that the Victorian Court cannot make such declarations when (as is frequently the case) it is exercising federal jurisdiction. ${ }^{53}$

As is perhaps de rigueur in New Zealand public law discourse, ${ }^{54}$ the Taylor Court was content to dismiss the High Court of Australia's concerns as a manifestation of Australian "exceptionalism". 55

50 Taylor (CA), above n 17, at [157]-[160], drawing on the two leading cases on the right to an effective remedy: Simpson v Attorney-General [Baigent's Case] [1994] 3 NZLR 667 (CA); and Taunoa v Attorney-General [2007] NZSC 70, [2008] 1 NZLR 429.

51 See Dicey, above n 49, at 198-199, discussed in Hickman, above n 24, at 48. See also Tom Hickman "Constitutional Dialogue, Constitutional Theories and the Human Rights Act 1998" [2005] PL 306 at 327 Stephenson, above n 5, at 129-133; and Taylor (CA), above n 17, at [46] (paraphrasing Dicey, above n 49, at 40): a law is "any rule that the courts will enforce".

52 Momcilovic v The Queen (2011) 245 CLR 1.

53 Although a narrow majority of judges in Momcilovic accepted that such declarations could be made when the Victorian Supreme Court was exercising state jurisdiction, even this part of the decision is hedged with confusion and uncertainty. This perhaps helps to explain why no such declaration has since been made whether in Victoria or under the equivalent power in s 32 of the Human Rights Act 2004 (ACT). For fuller discussion, see Will Bateman and James Stellios "Chapter III of the Constitution, Federal Jurisdiction and Dialogue Charters of Human Rights" (2012) 36 MULR 1; and Geiringer, above n 1, at 162.

54 See for example Michael Taggart "'Australian Exceptionalism' in Judicial Review" (2008) 36 FL Rev 1.

55 At [61]. 
There is, of course, something in that. In any event, in the absence of a written constitution, New Zealand is not lumped with an unbending and formalist prohibition on the judicial exercise of powers that might historically have been considered non-judicial. Our constitutional settlement "is not written in stone; it is not even written in paper" ${ }^{56}$ Our constitutional doctrines are, thus, free to evolve - an idea to which I return in Parts V and VI below. The point here, though, is a simple one: that an explanation grounded in the orthodox constitutional responsibility of judges to find, declare and enforce "law" fails to account satisfactorily for what is novel about the new declaratory jurisdiction.

\section{NARRATIVE TWO: THE NZ BILL OF RIGHTS AS FACILITATOR OF INTER-BRANCH DIALOGUE}

The Taylor Court, however, offers up an alternative vision of the courts' role under the NZ Bill of Rights in the notion of inter-branch "dialogue". ${ }^{57}$ The Court utilises this concept of dialogue, specifically, to formulate guidance as to the situations in which the jurisdiction to make a formal declaration should be exercised. (In short, one such situation is if, in all the circumstances, the "additional force" 58 of a formal remedy is necessary to advance such dialogue.) But the Court's invocation of the metaphor of dialogue taps, more generally, into a rich body of scholarship that invokes, or repudiates, the idea as an explanation for the constitutional relationships that inhere under the new generation of not-quite-supreme Anglo-Commonwealth bills of rights. ${ }^{59}$

Although the notion of constitutional dialogue has older antecedents, ${ }^{60}$ its prominence in contemporary Anglo-Commonwealth discourse began with Hogg and Bushell's seminal article, suggesting that the terms of the Canadian Charter of Rights and Freedoms leave room for legislativejudicial dialogue over the protection of human rights, and that this manifests in frequent "legislative sequels" to Charter-invalidating judicial decisions. ${ }^{61}$

56 John Laws "Law and Democracy" [1995] PL 72 at 81.

57 At [149] and following.

58 At [155]

59 The literature on dialogue is vast and shows no sign of abating. Some recent contributions include: Eoin Carolan "Dialogue isn't working: the case for collaboration as a model of legislative-judicial relations" (2016) 36 LS 209; Aileen Kavanagh "The Lure and Limits of Dialogue" (2016) 66 U Toronto LJ 83; Rainer Knopff and others "Dialogue: Clarified and Reconsidered" (2017) 54 Osgoode Hall LJ 609; Kent Roach The Supreme Court on Trial: Judicial Activism or Democratic Dialogue (revised ed, Irwin Law, Toronto, 2016); Stephenson, above n 5; and Alison L Young Democratic Dialogue and the Constitution (Oxford University Press, Oxford, 2017)

60 See for example Louis Fisher Constitutional Dialogues: Interpretation as Political Process (Princeton University Press, Princeton, 1988); Barry Friedman "Dialogue and Judicial Review" (1993) 91 Mich L Rev 577; and Stanley Ingber "Judging Without Judgment: Constitutional Irrelevancies and the Demise of Dialogue" (1994) 46 Rutgers L Rev 1473.

61 Peter W Hogg and Allison A Bushell "The Charter Dialogue between Courts and Legislatures (Or Perhaps the Charter of Rights Isn't Such a Bad Thing After All)" (1997) 35 Osgoode Hall LJ 75. See also Peter W 
Hogg and Bushell's article was published in 1997, on the eve of the enactment of the Human Rights Act 1998 (UK). Whatever its aptness in the Canadian context (on which opinions were, and are, mixed), ${ }^{62}$ the idea of dialogue had immediate resonance for some United Kingdom commentators. ${ }^{63}$ By the time the statutory bill of rights model migrated to Australia, just a few years later, the metaphor had taken such hold that it was to be found at the centre of official conceptions of the two Australian sub-national instruments. The final reports of the two consultation committees that gave rise to the ACT and Victorian statutes each explicitly proposed a "dialogical" model of human rights protection - one that would create multiple sites of inter-institutional engagement, rather than allowing the legislature or the judiciary a monologue on human rights protection. ${ }^{64}$

In New Zealand, the idea of dialogue as an explanation for the constitutional significance of the NZ Bill of Rights has not (yet) taken hold in quite the same way. ${ }^{65}$ One obvious reason for this is the

Hogg, Allison A Bushell Thornton and Wade K Wright "Charter Dialogue Revisited - Or 'Much Ado About Metaphors'" (2007) 45 Osgoode Hall LJ 2. For an interesting reflection on the academic obsession that resulted from Hogg and Bushell's work, see Jamie Cameron "Collateral Thoughts on Dialogue's Legacy as Metaphor and Theory: A Favourite from Canada" (2016) 35 UQLJ 157.

62 For a selection of views from the extensive Canadian literature, see Rosalind Dixon "The Supreme Court of Canada, Charter Dialogue, and Deference" (2009) 47 Osgoode Hall LJ 235; Grant Huscroft "Rationalizing Judicial Power: The Mischief of Dialogue Theory" in James B Kelly and Christopher P Manfredi (eds) Contested Constitutionalism: Reflections on the Canadian Charter of Rights and Freedoms (UBC Press, Vancouver, 2008) 50; Christopher P Manfredi and James B Kelly "Six Degrees of Dialogue: A Response to Hogg and Bushell" (1999) 37 Osgoode Hall LJ 513; Andrew Petter "Taking Dialogue Theory Much Too Seriously (Or Perhaps Charter Dialogue Isn't Such a Good Thing After All)" (2007) 45 Osgoode Hall LJ 147; Roach, above n 59; and Grégoire CN Webber "The Unfulfilled Potential of the Court and Legislature Dialogue" (2009) 42 Can J Pol Sci 443.

63 See for example Richard Clayton "Judicial Deference and 'Democratic Dialogue': The Legitimacy of Human Rights Intervention under the Human Rights Act 1998" [2004] PL 33; Richard A Edwards "Judicial Deference under the Human Rights Act" (2002) 65 MLR 859 at 866-868; Sandra Fredman "Bringing Rights Home" (1998) 114 LQR 538; Hickman, above n 1; Francesca Klug "The Human Rights Act - a 'third way' or a 'third wave' Bill of Rights" [2001] EHRLR 361; and Danny Nicol "The Human Rights Act and the Politicians" (2004) 24 LS 451. Carolan, above n 59, at 209, describes "dialogue" as "perhaps the leitmotif of the academic literature on the role of courts under the [Human Rights Act]". But see Kavanagh, above n 59, at 99-100, suggesting that (unlike Canada) dialogue did not emerge early as a dominant paradigm in the United Kingdom but positing that dialogue scholarship in the United Kingdom may now be on the rise.

64 ACT Bill of Rights Consultative Committee Towards an ACT Human Rights Act (2003); and Victorian Human Rights Consultation Committee Rights, Responsibilities and Respect: The Report of the Human Rights Consultation Committee (2005). For an account of the migration of "dialogue" from Canada to the Pacific (and the shifts in meaning that occurred along the way) see Scott Stephenson "Constitutional Reengineering: Dialogue's Migration from Canada to Australia" (2013) 11 ICON 870

65 But see Petra Butler "It Takes Two to Tango - Have They Learned Their Steps?" (Victoria University of Wellington Legal Research Paper No 136/2014, 15 August 2011) available at <https://ssrn.com>; Mark Elliott "Interpretative Bills of Rights and the Unwritten Constitution" [2011] NZ L Rev 591 at 613-617; Andrew Geddis "Inter-institutional 'Rights Dialogue' under the New Zealand Bill of Rights Act" in Tom Campbell, KD Ewing and Adam Tomkins (eds) The Legal Protection of Human Rights: Sceptical Essays (Oxford 
absence, in the NZ Bill of Rights, of an express power to make non-binding declarations of legislative inconsistency with protected rights. It is that mechanism that, in Britain and Australia, sits at the heart of many dialogical accounts of the legislative-judicial relationship under the statutory bill of rights model. ${ }^{66}$ The dual significance of Taylor in this regard is both that it confirms the existence, in New Zealand, of this supposed "engine for dialogue", ${ }^{67}$ and that it launches us into an explicit conversation about what the metaphor of dialogue might have to offer us.

The voluminous and contested international literature on dialogue poses significant questions about what precisely we mean when we characterise the legislative-judicial relationship as a dialogue, about the descriptive accuracy of the term, and about its normative desirability as a model (if we can even call it that) for legislative-judicial relations. ${ }^{68}$ Within the limited confines of this article I venture, rather more modestly, some observations about the function performed by the invocation of dialogue in the Taylor decision, and about its relationship with the legal benchmark narrative set out above.

Let me pick up the thread by suggesting that the invocation of dialogue by the Taylor Court is, in large part, an attempt to square the circle left by the inability of the legal benchmark narrative to account for the role of judges in making non-binding declarations of legal non-right. Thus, for example, the Taylor Court invokes the metaphor of dialogue explicitly in response to the charge of mootness: the question of legislative incompatibility is properly to be regarded as raising a "dispute", and a judicial opinion to that effect may serve a proper purpose, if it "furthers a dialogue among branches of government in a constitutionally appropriate manner". ${ }^{69}$ On this analysis, the courts'

University Press, Oxford, 2011) 87; Royden Hindle "Rights against Legislated Discrimination: A Sleeping Giant - Part 1A of the Human Rights Act 1993" [2008] NZ L Rev 213; Geiringer, above n 19, at 614-616 and 646-647; Sara Jackson "Designing Human Rights Legislation: 'Dialogue', the Commonwealth Model and the Roles of Parliaments and the Courts" (2007) 13 Auckland U L Rev 89; and Michael Taggart "Commentary: 'Dialogue' as Inter-Branch Communication" in Claudia Geiringer and Dean R Knight (eds) Seeing the World Whole: Essays in Honour of Sir Kenneth Keith (Victoria University Press, Wellington, 2008) 340 .

66 See for example $R v$ Momcilovic [2010] VSCA 50, (2010) 25 VR 436 at [95]; Victorian Human Rights Consultation Committee, above n 64, at 86; Dominique Dalla-Pozza and George Williams "The Constitutional Validity of Declarations of Incompatibility in Australian Charters of Rights" (2007) 12 Deakin L Rev 1 at 2 3; Fergal F Davis "Parliamentary Supremacy and the Re-Invigoration of Institutional Dialogue in the UK" (2014) 67 Parliamentary Affairs 137; and Stephenson, above n 64, at 891-892. See also Stephenson, above n 64 , at $883-884$, suggesting that other mechanisms said to promote institutional dialogue are also comparatively weak under the NZ Bill of Rights.

67 Hickman, above n 51, at 308.

68 As noted above, the Anglo-Commonwealth literature on dialogue is vast and expanding. For a selection of recent contributions, see above $\mathrm{n} 59$.

69 At [164] 
function is not just to determine legal rights, but to engage in a dialogue with the political branches (and an issue will not be moot if either of these functions are engaged).

The Taylor Court thus utilises the legal benchmark and dialogue narratives in parallel (and without explicitly addressing the relationship between them). But are they complementary? Or, in fact, discordant?

Some of the accounts of dialogue found in the international literature certainly suggest the latter. As we have seen, the Taylor Court's legal benchmark narrative draws on Diceyan conceptions of the special role of the courts as expounders of "law". By contrast, at least one strand of dialogue theory (a strand that I describe here, for the sake of simplicity, as "radical" dialogue theory) ${ }^{70}$ is distinctly un-Diceyan. It begins with a vision of shared authority on questions of consistency with human rights and locates the courts, not as authoritative expounders of the law, but as a voice in a conversation. ${ }^{71}$ On this view, when the courts issue a declaration of inconsistency, they are not authoritatively declaring the law; rather they are offering a provisional opinion on a question of moral principle. ${ }^{72}$ Regardless of whether one thinks this characterisation of the judicial role is normatively desirable, it is trite to suggest otherwise than that it involves a fundamental re-conceptualisation of the separation of powers. As Tom Hickman puts it: ${ }^{73}$

... the courts are transformed from arbiters of rights, albeit subject to legislative overrule, to a form of privileged pressure group whose function is to raise good reasons why a litigant's interests should be respected. It abandons the idea that the courts should hold government to fundamental principle and the law and repositions the courts within the forum of ordinary politics, providing not a check or balance, but counsel.

70 Other terms deployed in the literature to describe this radical strand of dialogue theory include "principleproposing dialogue": Hickman, above n 51, and "coordinate dialogue": Knopff and others, above n 59.

71 For example Tom Campbell "Incorporation through Interpretation" in Tom Campbell, KD Ewing and Adam Tomkins (eds) Sceptical Essays in Human Rights (Oxford University Press, Oxford, 2001) 79 at 99-100; Davis, above n 66, at 142; Manfredi and Kelly, above n 62, at 523-524; Danny Nicol "Law and politics after the Human Rights Act" [2006] PL 722 at 743; and Webber, above n 62. Rosalind Dixon's theory of judicial deference in "second look" cases is best understood as an instantiation of this more radical conception of what dialogue entails: Dixon, above n 62; and Rosalind Dixon "A Minimalist Charter of Rights for Australia: The United Kingdom or Canada as a Model?" (2009) 37 FL Rev 335 at 337.

72 Campbell, above n 71, at 99-100.

73 Hickman, above n 51, at 309-310. See also Kavanagh, above n 59, at 85; Jean Leclair "Réflexions critiques au sujet de la métaphore du dialogue en droit constitutionnel canadien" (2003) 63 Rev Barreau Québec 379 at 395-402 (translation: "Critical reflections on the metaphor of dialogue in Canadian constitutional law"); Roger Masterman "Interpretations, Declarations and Dialogue: Rights Protection under the Human Rights Act and Victorian Charter of Human Rights and Responsibilities" [2009] PL 112 at 123; Roach, above n 59, at 273; and Luc B Tremblay "The legitimacy of judicial review: The limits of dialogue between courts and legislatures" (2005) 3 ICON 617. 
We might, though, question how much of the baggage of radical dialogue theory the Taylor Court intended to drag into New Zealand law. Dialogue is, after all, an elastic concept. ${ }^{74}$ It is notable in this regard that the Taylor Court took care to stress that inter-branch dialogue is not unique to the NZ Bill of Rights, nor to constitutional disputes. Rather, it describes the "routine work of government", to which each of the three branches contributes by exercising its distinct role. ${ }^{75}$

This account echoes an alternative strand in the dialogue literature; one that is more harmonious with orthodox constitutional doctrine. On this view of what dialogue entails, the courts work in collaboration with the other branches, but are not transformed into mere proposers of provisional interpretations. Their role in the dialogue is, as it always has been, in "bringing common law reason to bear on legislative projects" and in "insulating fundamental principles" from majority sentiment. ${ }^{76}$ This less adventurous vision of dialogue sits far more squarely within our existing traditions (and far more harmoniously alongside the legal benchmark narrative).

Dialogue, then, is business-as-usual; no more or less than a synonym for Philip Joseph's "collaborative enterprise". ${ }^{77}$ The courts remain the "authoritative expositors of legal meaning". ${ }^{78}$ But if we are thus to cast off the baggage of radical dialogue theory, we must surely discard with it some of dialogue's explanatory power. For one thing, we no longer have an attractive explanation for why Parliament is entitled to disregard a judicial declaration of legal principle. On this more constitutionally orthodox account of dialogue, the declaration of incompatibility functions as "a device that allows courts to vent their scorn on a piece of rights defying legislation, thus excluding it from the integrity of the law". ${ }^{79}$ Parliamentary disregard of such a declaration is thus constitutionally aberrant, even as it is insulated from legal consequences.

74 Useful typologies of the multiple meanings attributed to dialogue in the academic literature are to be found in: Emmett Macfarlane "Conceptual Precision and Parliamentary Systems of Rights: Disambiguating 'Dialogue'" (2012) 17 Rev Const Stud 73; Knopff and others, above n 59; and Kent Roach "Constitutional and Common Law Dialogues between the Supreme Court and Canadian Legislatures" (2001) 80 Can Bar Rev 481. Some commentators suggest that the very elasticity of the concept of "dialogue" undermines its utility: see for example Macfarlane, above n 74; and Kavanagh, above n 59.

75 At [150].

76 Hickman, above n 51, at 317 and 324. See also Julie Debeljak "Parliamentary Sovereignty and Dialogue under the Victorian Charter of Human Rights and Responsibilities: Drawing the Line between Judicial Interpretation and Judicial Law-Making" (2007) 33 Monash LR 9 at 36; Peter Hogg "Discovering Dialogue" (2004) 23 SCLR (2d) 3 at 5; Roach, above n 59, at 277 and 279; and Roach, above n 74, at 483.

77 Philip A Joseph "Parliament, the Courts, and the Collaborative Enterprise" (2004) 15 KCLJ 321; and Taylor (CA), above n 17, at [149], $\mathrm{n} 196$ : "The metaphor of dialogue is consistent with the view that government is a collaborative enterprise." For additional references in the decision to "collaborative enterprise", see Taylor at [47], n 46, [51], nn 59-62 and [53], n 65.

78 Joseph, above n 77, at 330.

79 Hickman, above n 51, at 327. 
Radical dialogue theory, on the other hand, supplies an explanation for parliamentary intransigence based on the notion of shared authority. No one branch has a monopoly in settling the meaning and scope of rights; Parliament's view of the scope of protection is as authoritative, perhaps more so, than the courts'. ${ }^{80}$ This idea is encapsulated, strikingly, in the name given to the declaratory power in the Victorian Charter: a declaration, neither of inconsistency nor of incompatibility, but of "inconsistent interpretation". 81

Radical dialogue theory thus functions as a self-conscious attempt to differentiate the form of constitutionalism being exercised under the new generation of Anglo-Commonwealth bills of rights from the traditional modes of human rights protection found in systems of both judicial and parliamentary supremacy. It takes its place alongside other attempts to cast this "new Commonwealth model" of human rights protection as an innovative, and normatively desirable, form of constitutionalism; one that concentrates less on which agency has the final word, as on the interactions that might profitably occur along the way. ${ }^{82}$

It is perhaps understandable why a New Zealand court, seeking to explain and to justify a novel exercise of judicial power in the absence of express statutory authority, would not wish to associate itself directly with this drive to differentiate and would prefer to emphasise continuity with existing traditions. But ultimately, the Taylor Court cannot avoid confronting the fact that the issuance of a formal but non-binding declaration of legal non-right is not quite business as usual. It involves, at very least, an extension of common law dialogical method.

And the Court does, in fact, acknowledge that there is something qualitatively different about the kind of dialogue facilitated by the making of a formal declaration. In an "incompatibility claim", the Court opines, the judicial contribution to the inter-branch conversation is "more pointed". ${ }^{83}$ The declaratory remedy utilises the machinery of government to bring the Court's view on legislative incompatibility formally to the attention of the political branches. And, in doing so, it triggers a reasonable constitutional expectation that those branches will respond by "reappraising the legislation and making any changes that are thought appropriate". ${ }^{84}$ In other words, a formal declaration is dialogue on steroids; a way for the Court to raise its voice if it feels it will otherwise be ignored.

80 Nicol, above n 71, at 742 .

81 Charter of Human Rights and Responsibilities Act 2006 (Vic), s 36. See Simon Evans and Carolyn Evans "Legal redress under the Victorian Charter of Human Rights and Responsibilities" (2006) 17 PLR 264 at 271; Masterman, above n 73, at 124; and George Williams "The Victorian Charter of Human Rights and Responsibilities: Origins and Scope" (2006) 30 MULR 880 at 903. But see James Allan "The Victorian Charter of Human Rights and Responsibilities: Exegesis and Criticism" (2006) 30 MULR 906 at 915-916.

82 See for example Gardbaum, above n 5; and Stephenson, above n 5 .

83 At [150].

84 At [151]. 
In its invocation of dialogue, we thus see the Taylor Court navigating its way through difficult shoals. The metaphor of dialogue must be allowed to do enough work to justify a novel jurisdiction (and to square the circle left by the legal benchmark narrative) but not so much as to invite the charge of unauthorised constitutional experimentation. Radical dialogue goes too far; it involves a constitutional departure of a kind for which the Taylor Court, it seems, has no real stomach.

But does the more orthodox vision of dialogue as collaborative enterprise go far enough? If dialogue is what the courts do all the time, then how can it provide an explanation for the unique judicial activity of making a non-binding declaration of legal non-right? Does it, in short, succeed in squaring the circle left by the legal benchmark narrative?

\section{NARRATIVE THREE: THE COMMON LAW-FUELLED BILL OF RIGHTS}

The answer to that question is arguably supplied by the third narrative - one that underlies the other two, and that knits together the Court's vision of the significance of the NZ Bill of Rights within New Zealand's constitutional arrangements. According to this narrative, if we want to understand the courts' role in policing and enforcing the NZ Bill of Rights, we must look not (or not primarily) to the statutory regime, but to the common law.

Thus, in considering whether the New Zealand courts have a jurisdiction to make declarations of inconsistency, the Taylor Court turns, first, not to the question of statutory authorisation, but to the common law jurisdiction of the superior courts. In an account admittedly somewhat devoid of reference to New Zealand's colonial history, ${ }^{85}$ the Court asserts the independent source of this common law judicial authority to expound the law - in the political settlement reached after the Glorious Revolution. ${ }^{86}$ The three branches of government - legislative, executive and judicial - may be "co-dependent", but each is "sovereign within its sphere of authority" in the sense that they each "inhere in any sovereign state" and may "act without the permission or authority of the others". ${ }^{87}$ Citing Philip Joseph's work, the Court goes on to note that: "On this view, government is a

85 Beyond a brief allusion at [62] to the New Zealand Constitution Act 1852 (UK) 15 \& 16 Vict c 72, there is no discussion of the role played by legislation and colonial ordinances during the $1840 \mathrm{~s}$ and $1850 \mathrm{~s}$ in establishing New Zealand's justice system and its significance (or not) for the assertion of an independent source of common law authority. Compare Sian Elias "Transition, Stability and the New Zealand Legal System" (2004) 10 Otago LR 475 at 478-480.

86 At [47]-[50].

87 At [51]. The Court supports this assertion, in part, by reference to s 4(1)(b) of the Parliamentary Privilege Act 2014, and its acknowledgement of the separateness and independence of the legislative and judicial branches within their "proper sphere of influence". 
'collaborative enterprise', with each branch exercising distinct but complementary powers to a common end." 88

This account of the courts' common law powers then provides the foundation, in Taylor, for key assertions underlying the other two narratives: that Parliament is subject to "law", which the courts declare; and that inter-branch dialogue is a time-honoured (common law) judicial function. Ultimately, the Taylor Court concludes that the jurisdiction to make declarations of inconsistency "finds its source in the common law jurisdiction of the higher courts to answer questions of law" and is "confirmed" by the NZ Bill of Rights. ${ }^{89}$

The Taylor Court's somewhat controversial assertion of a tri-polar sovereignty (residing in the legislature, judiciary and executive) will no doubt attract the interest of sovereignty theorists. ${ }^{90}$ In this article, however, I do not wish to concern myself with that formal claim. My interest here is, more specifically, in the Taylor Court's reach to the authority of the common law to explain and legitimise the new declaratory remedy, and in what this tells us about the relationship between the common law and the NZ Bill of Rights more generally. There is nothing novel, in itself, in recognition of the closeness of that relationship. The linkages between s 6 of the NZ Bill of Rights and common law

88 At [51], citing Joseph, above $\mathrm{n} 77$ (footnotes omitted). It is perhaps worth noting that Joseph himself would probably depreciate this analogy between his own work and the idea of twin or multiple sovereignties, as he believes the latter to be "an oxymoron that is better avoided": Joseph, above n 77, at 333.

89 At [109]. For want of space, this article does not pursue the intriguing questions thrown up by Taylor about the interdependence (or not) of the two sources of jurisdiction the Court identifies. For example, does the common law authorise declarations of legislative inconsistency with other kinds of hierarchically inferior "law" - international law, for example, or (indeed) the common law itself? See at [59] for a hint that the former, at least, might have been anticipated. See also Butler, above n 15, at 59, questioning whether such a declaration might be available in relation to the Treaty of Waitangi.

90 For claims in the British context of bipolar sovereignty (divided between the Queen in Parliament and the Queen in its courts), see especially TRS Allan Constitutional Justice: A Liberal Theory of the Rule of Law (Oxford University Press, Oxford, 2001) at 14 and 201; CJS Knight "Bi-Polar Sovereignty Restated" (2009) 68 CLJ 361; Stephen Sedley "Human Rights: a Twenty-First Century Agenda" [1995] PL 386 at 389; Stephen Sedley "The Common Law and the Constitution" in Lord Nolan and Stephen Sedley The Making and Remaking of the British Constitution (Blackstone Press, London, 1997) 15; X Ltd v Morgan-Grampian (Publishers) Ltd [1991] 1 AC 1 (HL) at 48 per Lord Bridge of Harwich; and Hamilton v Al-Fayed [1999] 3 All ER 317 (CA) at 320 per Lord Woolf MR. For a critique of the notion of bipolar sovereignty, see JWF Allison The English Historical Constitution: Continuity, Change and European Effects (Cambridge University Press, Cambridge, 2007) at 216-221. Claims of tri-polar sovereignty (residing also in the executive) are less common, and are resisted by key proponents of bipolar sovereignty such as Knight and Sedley. The Taylor Court seems to have relied for this assertion primarily on John Salmond's early 20th century claim that sovereignty in Britain is divided into a legislative sovereignty (residing in the Crown and the two Houses of Parliament) and an executive sovereignty (residing in the Crown by itself). See John Salmond Jurisprudence (7th ed, Sweet \& Maxwell, London, 1924) at Appendix II; and Taylor (CA), above $\mathrm{n}$ 17, at [51], n 59. Further support might be found in JAG Griffith "The Common Law and the Political Constitution" (2001) 117 LQR 42 at 45-51 (in which Griffith objected to the omission of the executive from the bipolar sovereignty narrative). 
interpretive method are, in any event, well understood. ${ }^{91}$ Nevertheless, it is perhaps notable that in no other jurisdiction to have recognised a power to make non-binding declarations of legislative incompatibility has the relevant authority been sourced, at least self-consciously, in the common law. Where foreign courts have exercised such a power, they have done so for no other reason than because the relevant human rights statute so directs. And in the New Zealand literature, the case for recognising a power to make declarations of inconsistency has tended to be framed in terms of legislative implication, not common law power. ${ }^{92}$

The Taylor Court's decision to reach to the authority of the common law to explain and legitimise the new declaratory remedy is thus somewhat novel. And for at least three reasons, it is also interesting and significant. First (and perhaps least remarkably) it reminds us that the text of the NZ Bill of Rights, read in its historical context, does not obviously invite abrupt constitutional departure. ${ }^{93}$ The NZ Bill of Rights must, somehow or other, be explained within our existing constitutional paradigm.

But secondly, this reach to the stability of the common law to explain the novelty of the declaratory jurisdiction reminds us that our existing constitutional traditions are, themselves, sufficiently flexible to accommodate renewal. ${ }^{94}$ The common law has always looked back to the stability of the past in order to innovate for the future. ${ }^{95}$ It represents permanence but also change; endurance, but also rupture. In short, the common law is always something-a-little-different, just as it is business-as-usual.

91 See for example $R v$ Hansen, above n 37, at [13] per Elias CJ and at [250]-[251] per McGrath J; and Claudia Geiringer "The Principle of Legality and the Bill of Rights Act: A Critical Examination of $R v$ Hansen" (2008) 6 NZJPIL 59. Paul Rishworth suggests, more broadly, that it was common law interpretive method that supplied the critical idea underlying the legal benchmark narrative: that the NZ Bill of Rights mandates "judicial inquiry into what count[s] as consistency with rights": Rishworth, above n 3, at 174-175. See also Paul Rishworth "Writing things unwritten: Common law in New Zealand's constitution" (2016) 14 ICON 137 at 153 .

92 See Butler, above n 15, at 51.

93 See $R v$ Hansen, above $\mathrm{n}$ 37, at [156] per Tipping $\mathbf{J}$ and at [238]-[246] per McGrath J (rejecting British-style strong remedial interpretation for similar reasons).

94 On the capacity of the common law for renewal, see generally Elias, above n 85, at 479, 483 and 486; Lord Goff "Maccabean Lecture in Jurisprudence: The Search for Principle" (1983) 69 Proc Brit Acad 169 (also discussing the contribution of scholars to the evolutionary character of the common law); Lord Reid "The Judge as Law Maker" (1972) 12 JSPTL 22; and Walter Schaefer "Precedent and Policy" (1966) 34 U Chi L Rev 3 at 6.

95 Elias, above n 85, at 482; Goff, above n 94, at 184; Allan C Hutchinson Evolution and the Common Law (Cambridge University Press, Cambridge, 2005) at 1-2; Schaefer, above n 94, at 24; and Frederick Schauer "Precedent" (1987) 39 Stan L Rev 571 at 572-575. See also Ronald Dworkin Law's Empire (Fontana Press, London, 1991) at ch 7, outlining his theory of "law as integrity". 
Thus, we see the Taylor Court reaching back to time-honoured propositions such as "[t]he judicial function extends to answering questions of law" in order to innovate without disrupting. ${ }^{96}$ If this kind of law-expounding is a little different from the usual kind (and if this kind of dialogue is a little different from the usual dialogue) these are changes that the Court can accommodate within an evolving, but enduring, common law tradition. As legal historian SFC Milsom put it, "out of the old hat there comes a new rabbit". 97

Thirdly, from a comparative perspective, this vision of the common law as the engine of judicial power under the NZ Bill of Rights is interesting because it is arguably a point of distinction with the other jurisdictions to have adopted the so-called "new Commonwealth model" of human rights protection. This is, in part, a point of negation. Arguably, in those other jurisdictions, an intention to innovate (constitutionally) was far more manifest in the legislative history. Thus, the Canadian Charter was enacted as part of a formal Constitution, the Human Rights Act 1998 (UK) was designed to naturalise the European Convention on Human Rights (and stem the flow of United Kingdom cases to Strasbourg), and the two Australian sub-national human rights charters were, as we have seen, explicitly cast, as instruments of constitutional dialogue. In each instance, such considerations opened the door for the constitutional significance of the respective instruments to be framed (at least by some) in the language of transformation - as, for example, by recourse to radical dialogue theory or to the British notion of strong remedial interpretation..$^{98}$

Viewed against this background, one might be tempted to treat the close linkages between the NZ Bill of Rights and the common law as a shorthand for absence or abnegation. If one begins (as much of the comparative scholarship does) with a project of differentiation - to account for what is constitutionally novel about the new generation of Anglo-Commonwealth bills of rights - it is difficult not to regard resort to common law method as a sign of pathology. Seen in this light, for example, the Hansen Court's rejection of British-style remedial interpretation in favour of something more aligned with the common law principle of legality demonstrates that the NZ Bill of Rights regime is not truly "distinct" but is, rather, indistinguishable from the "traditional paradigm" of parliamentary sovereignty. ${ }^{99}$

96 At [62].

97 SFC Milsom "Reason in the Development of the Common Law" (1965) LQR 496 at 497. See also Hutchinson, above $\mathrm{n} 95$, at 1 : "the motto of the common law might be a slight twist on the old adage that plus c'est la même chose, plus ça change".

98 See for example Ghaidan v Mendoza [2004] 2 AC 557 (HL). In Australia, the language of transformation has turned out to be problematic for a different reason: because it brings these sub-national statutory regimes into tension with federal constitutional doctrine. See Momcilovic v The Queen, above n 52; Bateman and Stellios, above n 53; and Geiringer, above n 1.

99 See for example Stephenson, above n 5, at 187-188 and 191-193. 
This is not wholly untrue, nor is it the whole story. Specifically, such an analysis fails to account satisfactorily for the fact that the traditional paradigm of legislative supremacy is not a static benchmark. ${ }^{100}$ The NZ Bill of Rights was layered onto a system that was, and is, in constant flux. That can always be said of the common law. But it was particularly so of the common law's stance towards the protection of human rights in the decades immediately preceding and succeeding the enactment of the NZ Bill of Rights. Consider, for example, Lord Cooke's (obiter) assertions of a common law power to disapply legislation in the 1980s; and the pan-Anglo-Commonwealth reassertion of a strong principle of legality in the 1990s. ${ }^{101}$

Taylor reminds us, lest we have forgotten, of the regenerative potential of the common law. And it also reminds us that the relationship between the common law and the statutory regime is not one way. ${ }^{102}$ According to the Taylor Court's account, it is to the common law that we must look to explain the exercise of judicial power under the NZ Bill of Rights. But surely we are not fooled for a moment that the common law has cut the power to make non-binding declarations of legislative inconsistency out of whole cloth. Rather, what we see here is the common law and the NZ Bill of Rights travelling in tandem; each exerting pressure on the other, and each evolving in response. If the NZ Bill of Rights is no more than the common law, the common law is exhorted to be at least as much as the NZ Bill of Rights. In Taylor, we see the common law rise to meet that challenge. ${ }^{103}$

Looked at in this light, we can now recast the judicial affirmation of the relationship between the NZ Bill of Rights and the common law as one, not simply of abnegation, but of potentiality. The

100 For my broader critique of this genre of comparative scholarship, see Claudia Geiringer "Review: Scott Stephenson, From Dialogue to Disagreement in Comparative Rights Constitutionalism" (2017) 15 ICON (forthcoming); Claudia Geiringer "Moving Beyond the Constitutionalism/Democracy Dilemma: 'Commonwealth Model' Scholarship and the Fixation on Legislative Compliance" in Mark Elliott, Jason NE Varuhas and Shona W Stark (eds) The Unity of Public Law? Doctrinal, Theoretical and Comparative Perspectives (Hart Publishing, Oxford, 2018) (forthcoming).

101 See Rishworth, above n 91, at 144-147.

102 See Elliott, above n 65, at 606 and 608-609. For discussion, more generally, of the symbiotic relationship between common law and statute, see for example Jack Beatson "The Role of Statutes in the Development of Common Law Doctrine" (2001) 117 LQR 247; Lord Bingham "The Common Law: Past, Present and Future" (1999) 25 CLB 18 at 27 (they "feed and refresh each other"); Andrew Burrows "The Relationship between Common Law and Statute in the Law of Obligations" (2012) 128 LQR 232; and John Burrows "Common Law among the Statutes: The Lord Cooke Lecture 2007" (2008) 39 VUWLR 401 at 406-407. Elias, above n 86 , at 484, suggests that New Zealand judges have been particularly willing to recognise the symbiotic nature of this relationship. For a helpful review of the earlier and now outdated view that the common law and statute are like "oil and water", see Beatson, above n 102, at 248-251.

103 We may perhaps think of Taylor in this regard as New Zealand's Thoburn v Sunderland City Council [2002] EWHC 195 (Admin), [2003] QB 151 - in which Laws LJ explained the willingness of the British courts to enforce the statutory direction giving hierarchical priority to European Union law in terms of the evolutionary stance of the common law with respect to the enforcement of "constitutional" statutes. 
language of transformation has been discarded in favour of the language of continuity. But simultaneously, the transformative potential of the common law has been affirmed.

\section{CONCLUDING THOUGHTS}

We began this article with the conundrum posed by the fundamental ambivalence emanating from the text, and enactment history, of the NZ Bill of Rights. What does the Act mean for the judiciallegislative relationship? Is the NZ Bill of Rights business-as-usual? Or something-completelydifferent? Did its enactment reflect a moment of departure? Or of continuity?

Far from working our way out of this problem, it turns out the Taylor decision has worked us deeper into it. We now see that the ambivalence of the NZ Bill of Rights cannot be sheeted home entirely to its text and drafting history. Rather, it reflects a deeper ambivalence that lies at the heart of our unwritten constitution. ${ }^{104}$ In our constitution, after all, the ordinary can be constitutional, and the constitutional is always (sort of) ordinary. The NZ Bill of Rights is undoubtedly an ordinary statute. And it is assuredly a constitutional statute.

The same, too, can be said of the constitutional credentials of the common law. It, too, is both ordinary and special. It is fundamental law that cradles the legal system. ${ }^{105}$ And it is ordinary law, amenable to statutory override. It is a vehicle for stability and tradition. But it is a vehicle, too, for renewal and transformation.

From this it should also now be clear that, in answering the ultimate question in Taylor whether New Zealand's superior courts should recognise a jurisdiction to make declarations of legislative inconsistency, the Taylor Court's reach to the authority of the common law can provide no more than a starting point. The common law can provide a basis for renewal and transformation. But it does not (and should not) always do so. The important questions are when, and how, and why?

On the other hand, by refocusing our attention away from a search for implied statutory meaning, and onto the authority of the common law, the Taylor Court's approach does say something of interest about the framework within which that ultimate question might be addressed. Large tomes have, of course, been written on the manner and circumstances in which the common law accommodates (or should accommodate) change. ${ }^{106}$ For the purposes of this article, however, two brief points must suffice.

104 See Geiringer, above n 1, at 173-174.

105 William N Eskridge Jr and John Ferejohn "Super-Statutes" (2001) 50 Duke LJ 1215 at 1264-1266; and Philip A Joseph Constitutional and Administrative Law in New Zealand (4th ed, Thomson Reuters, Wellington, 2014) at [2.4].

106 For example Melvin Aron Eisenberg The Nature of the Common Law (Harvard University Press, Cambridge (Mass), 1988); and Hutchinson, above n 95. 
The first is that if the common law is to provide the ultimate basis for recognition of the new jurisdiction, then any such change must be capable of being accommodated within the tentative and incremental techniques of law-making characteristic of common law method. "The method of the common law in change is", says Elias CJ extra-judicially, "modest and careful". ${ }^{107}$ This may help to explain the elaborate dance that the New Zealand courts have been performing around the possibility of recognising a declaratory remedy for the last two decades. ${ }^{108}$

The second point is that resort to the authority of the common law helps us to focus away from the arid question of statutory authorisation and onto the competing policy considerations that might support the desirability, or not, of recognising (or exercising) the new remedy. ${ }^{109}$ Recognition of such a jurisdiction would clearly enliven, in interesting and perhaps fruitful ways, the courts' relationship with the legislative branch, and its role as a guardian of fundamental principle subject to the ultimate law-making authority of Parliament. ${ }^{110}$ On the other hand, as we have seen, the novelty of the declaratory jurisdiction lies in the pressure that it places on orthodox conceptions of the judicial role. We should not assume that this comes without dangers - for example, of erosion of respect for the integrity of the law and (if the courts' pronouncements were to be routinely disregarded) of the institutional standing of the judiciary.

In short, as Scott Stephenson has astutely suggested, there are "normative trade-offs" to be made here. ${ }^{111}$ Whether, and how, those trade-offs should be made is now in the hands of the Supreme Court. The wisdom of the Court of Appeal's decision is in suggesting that it is flexibility and the authority of the common law (at least as much as the implications to be derived from the text of the NZ Bill of Rights itself) that, ultimately, allow them to do so.

107 Elias, above n 85, at 483. See also Eisenberg, above n 106, at 47-49; Milsom, above n 97, at 498; Schaefer, above n 94, at 14; and Southern Pacific Co v Jensen 244 US 205 (1917) at 221 per Holmes J dissenting: "judges do and must legislate, but they can do so only interstitially; they are confined from molar to molecular motions".

108 For a full account of this dance, see Geiringer, above n 19.

109 See Eisenberg, above n 106, at ch 4 and 43-46.

110 See Conor Gearty Can Human Rights Survive? (Cambridge University Press, Cambridge, 2006) at 95-96, describing the declaration of incompatibility as part of the "genius" of the Human Rights Act 1998 (UK); and Stephenson, above $\mathrm{n} 5$, at ch 6 especially, suggesting that the desirability of the declaration of incompatibility is in the way it facilitates "direct inter-institutional disagreement".

111 Stephenson, above $\mathrm{n} 5$, at ch 7 and especially at 129-132, identifying, specifically, the constitutional doctrines of separation of powers and the rule of law as normative trade-offs that sit in tension with the promotion of "direct inter-institutional disagreement" through mechanisms such as the declaration of incompatibility). For my broader critique of Stephenson's model, see Geiringer "Review: Scott Stephenson", above n 100; and Geiringer "Moving Beyond the Constitutionalism/Democracy Dilemma", above n 100. 